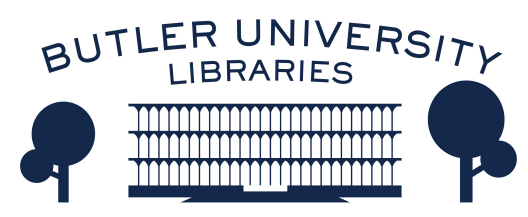

Journal of Hindu-Christian Studies

Volume 14

Article 22

January 2001

\title{
Book Review: "Christianity is Indian: The Emergence of an Indigenous Community"
}

Anand Amaladass

Follow this and additional works at: https://digitalcommons.butler.edu/jhcs

Part of the Religion Commons

\section{Recommended Citation}

Amaladass, Anand (2001) "Book Review: "Christianity is Indian: The Emergence of an Indigenous Community"," Journal of Hindu-Christian Studies: Vol. 14, Article 22.

Available at: https://doi.org/10.7825/2164-6279.1265

The Journal of Hindu-Christian Studies is a publication of the Society for Hindu-Christian Studies. The digital version is made available by Digital Commons @ Butler University. For questions about the Journal or the Society, please contact cbauman@butler.edu. For more information about Digital Commons @ Butler University, please contact digitalscholarship@butler.edu. 
recognition from both Britain's immigrant Hindu community and Britain's secular Christian host society. This timely and welltold story should be in every University library and would enliven any graduate or senior undergraduate course on Hinduism.

Harold Coward

University of Victoria

\section{Christianity is Indian: The Emergence of an Indigenous Community. Roger E. Hedlund (Ed.). Delhi: ISPCK, 2000, xiv + 458 pp.}

THE TITLE of this volume might sound rather apologetic, as if one tries to assert one's right to exist in a country like India. Thus it makes the readers curious about the content of the book. There are 27 entries in this volume apart from the introduction of the editor, divided into three parts as : historical and critical studies, narratives of emerging movements and accounts of participants and observers. These are papers presented in a seminar held by Hyderabad in 1998.

The editor points out the goal of this publication: It "is designed to advance the understanding of Christianity in the contemporary Indian context, strengthen the self-identity of India's Christian community, and document the historical importance of Christianity in the region as well as provide information for historians and research scholars." (p. xi).

The title itself is quite suggestive at a time when a debate is going on about the national identity of the Indian citizens: who is an Indian and who is a foreigner? Christianity and Islam are considered to be foreign to India, since they had their origin outside of India. It is historically true that Christianity in India is as old as Christianity itself. But the question is whether it has become part of "Indian culture".

This volume enumerates several attempts of Christians to be "indigenous". Indigenous churches in different parts of India are presented from Kerala, Tamilnadu, Andhra, Bengal and so on. Integration of Christian presence with the Indian culture is highlighted through the example of Roberto de Nobili, Sadhu Sundar Singh and others.
The Christian presence among the Dalits and tribals is another important feature of this book. Thus, this volume is a useful document to assess the Christian presence in India.

The editor remarks that the various Christian movements in India "are demonstrations of the translatability of the Gospel, an authentic Indian incarnation of Christian faith" (p. ix). This volume occasions also for raising several questions. It is rather strange that even after 2000 years of Christian presence in India, the Christians have to prove that Christianity is Indian. One has still to explain the historical fact that after 2000 years of missionary work, this community's strength is about two and a half percent of the total population - a marginalized group, as one could say in today's context. All its struggle seems to be in integrating with the major community in India.

Christian contribution to the national culture is also minimal for example compared to the Islamic presence in India, in spite of its claim to run several educational and medical institutions. It has not acted as an antidote to the several ills of the Indian society like the caste factor that is vitiating also the Christian community in India. This book is said to be opening the door for further research in this direction and hence it is a welcome contribution to the Christian thinkers.

Anand Amaladass S. J. Chennai, India 